\title{
Predicting long-term hydrological change caused by climate shifting in the 21st Century in the headwater area of the Yellow River Basin
}

\author{
Jingyi $\mathrm{Hu}^{1}$, Yiping $\mathrm{Wu}^{1}$, Pengcheng $\mathrm{Sun}^{1}$, Fubo Zhao ${ }^{1}$, Ke Sun ${ }^{1}$, Tiejian $\mathrm{Li}^{2}$, Bellie \\ Sivakumar $^{3}$, Linjing Qiu ${ }^{1}$, Yuzhu Sun ${ }^{1}$, and Zhangdong $\mathrm{Jin}^{4}$ \\ ${ }^{1}$ Xi'an Jiaotong University \\ ${ }^{2}$ Tsinghua University \\ ${ }^{3}$ Indian Institute of Technology Bombay \\ ${ }^{4}$ IEECAS
}

April 27, 2021

\begin{abstract}
The Qinghai-Tibetan Plateau (QTP) is one of the amplifiers of global climate change. The headwater area of the Yellow River Basin (HYRB) on the QTP is the dominant water source region for the whole Yellow River Basin (YRB). However, the sensitive responses of hydrological processes to the intensifying climate change are exerting high uncertainties to the water cycle in the HYRB. The aim of this study was to investigate the potential climate change under three Representative Concentration Pathways (RCP 2.6, 4.5, and 8.5) and their hydrological impacts in this region using the ensemble climate data from eight general circulation models (GCMs) and the Soil and Water Assessment Tool (SWAT). Compared to the baseline (1976-2015), the projected climate indicated a rise of $7.3-7.8 \%$ in annual precipitation, $1.3-1.9^{\circ} \mathrm{C}$ in maximum air temperature, and $1.2-1.8^{\circ} \mathrm{C}$ in minimum air temperature during the near future period $(2020-2059)$, and an increment of $9.0-17.9 \%, 1.5-4.5^{\circ} \mathrm{C}$, and $1.3-4.5^{\circ} \mathrm{C}$ in precipitation, maximum and minimum temperature, respectively, during the far future period (2060-2099). The well-simulated SWAT modeling results suggested that due to a wetter and warmer climate, annual average actual evapotranspiration (AET) would increase obviously in the future (31.9-35.3\% during the near future and 33.5-54.3\% during the far future), which might cause a slight decrease in soil water. Water yield would decrease by $16.5-20.1 \%$ during the near future period, implying a worsening water crisis in the future. Till the end of this century, driven by the increased precipitation, water yield would no longer continue to decrease, with a decline by $15-19.5 \%$. Overall, this study can not only provide scientific understanding of the hydrological responses to the future climate in both semi-arid and alpine areas, but also contribute to the decision support for sustainable development of water resources and protection of eco-environment in the HYRB.
\end{abstract}

\section{Hosted file}

Manuscript_handle.pdf available at https://authorea.com/users/410253/articles/519709predicting-long-term-hydrological-change-caused-by-climate-shifting-in-the-21st-centuryin-the-headwater-area-of-the-yellow-river-basin

\section{Hosted file}

Figures.pdf available at https://authorea.com/users/410253/articles/519709-predictinglong-term-hydrological-change-caused-by-climate-shifting-in-the-21st-century-in-theheadwater-area-of-the-yellow-river-basin

\section{Hosted file}

Tables.pdf available at https://authorea.com/users/410253/articles/519709-predictinglong-term-hydrological-change-caused-by-climate-shifting-in-the-21st-century-in-the- 
headwater-area-of-the-yellow-river-basin 